https://doi.org/10.18778/7525-969-8.25

\title{
Wiestaw Walkiewicz
}

\section{Czarnogórców droga do wolności}

Autor szkicu winien jest poczynienia, kilku przynajmniej, objaśnień w kwestiach formalnych. Sytuują się pośród nich takie chociażby, jak fakt, że Czarnogórcy de facto nigdy, tj. ani pod Porta ${ }^{1}$, ani włosko-niemiecką okupacja, ani w fuzji z belgradzkim centralizmem, do końca niepodległości się nie wyzbyli ${ }^{2}$. Nie sposób też nie pochylić się nad pytaniem, czy mieszkańcy tej republiki - jedynej, która w 1991 r. nie skorzystała z opcji sukcesji na gruzach rozpadającej się wielonarodowej federacji, kierowali się przez półtorej dekady oportunizmem i obawami przed „nowym” czy może swoistym, choć uwierającym, lojalizmem i solidaryzmem z „serbskim Piemontem”? ${ }^{3}$ Czy wreszcie uwikłana we wspólne z prawosławnymi sąsiadami doświadczenia historii, język, podobieństwa mentalne, Czarnogóra w sposób naturalny nie ciążyła ku więzom z liczebniejszym i silniejszym partnerem, realizując model chociażby orientacji białoruskiej „wczesnego Łukaszenki”? Czy - biorąc pod uwagę, odwrotne jak w tym ostatnim przypadku, głębokie poczucie tożsamości, godności narodowej, budowane na szczytnej tradycji, zapisywaniu kart oręża, od odpierania Węgrów, wojen bałkańskich, do I i II wojny światowej - „rozwodu” nie celebrowano nadmiernie długo?

I czy może z „rozciagliwości w czasie” nie wynikały, np. w fazie sukcesów „jugo-armii” (1991-1993) ekstraprofity, czy przeciwnie - postawę tę złożyć trzeba na karb empatii z uwiedziona nacjoideologia, izolowaną matką Serboslawią? A może salwując się konstrukcją Henryka Batowskiego, iż sięgając po rewolwer w Skupsztinie przeciw uwłaczającym Królestwu delegatom chorwackim, Puniša

${ }^{1}$ W latach 1488-1499 księstwo Zety, od ostatniej ćwierci XII w. poddawane ekspansji serbskiej, podbite zostało przez Turków, jakkolwiek najeźdźca nie panował nad wysokogórskimi enklawami.

${ }^{2}$ W zderzeniu z ekspansją otomańską na Bałkanach Zachodnich nie bez znaczenia dla przechowania pierwiastków narodowo-wolnościowych pozostawało życzliwe Podgoricy stanowisko Petersburga, z jakim w Stambule liczyć się musiano.

${ }^{3}$ De facto funkcję taką przyjęła na siebie Serbia w wieku XIX, z uwagi na rolę sił zbrojnych Królestwa w zwycięstwie Ententy, skutkującą przychylnością Konferencji Paryskiej dla Państwa SHS. Określenie południowo-słowiańskiego Piemontu zakotwiczyło, $\mathrm{w}$ istocie niepoprawnie, najpierw w narracji dwudziestolecia, później w odniesieniu do NOB, czyli etosu narodowo-wyzwoleńczego lat 1941-1945. 
Račić zachował się tak, jak poseł z Czarnogóry zachować się musiał ${ }^{4}$ da się trzy ćwierci wieku później powiedzieć, że stanowisko tamtejsze inne być nie mogło? W końcu, parafrazując deklarację Milo Đukanovicia, że nawet jeśli „to nie ich wojna była", to czy wypadało opuścić pobratymców, którym na miasta, nie koszary, na osobowe pociagi czy szkolne busy NATO zrzucało - pokojowo bomby wzbogacone odrobiną uranu...

Nim świat zdążył się przyzwyczaić do myśli, że wszedł właśnie w Nowe Millenium, a Vojislav Koštunica poczynić ostatnie poprawki w przygotowywanym na 10 stycznia 2001 r. tekście o wizji współpracy na linii Belgrad-Podgorica, „nieznany sprawca” zastrzelił Darko Raspopovicia - szefa czarnogórskiej policji. Odnotowawszy incydent „z konotacją swoistą dla nowej odsłony bałkańskiej”, przedkładając projekt, prezydent dowodził, że oba państwa powinny być reprezentowane na zewnątrz przez organy federacyjne, bez potrzeby uznania międzynarodowego - jak życzyć sobie na południowych ostańcach Gór Dynarskich zaczęto - podmiotów odrębnych.

Na serbskiej scenie niczego specjalnego do układu sił politycznych nie wnosiła powtórka wyborów do parlamentu z 23 grudnia 2000 r., ćwiczona na 19 zaledwie z 8 tys. okręgów. Zdecydowanie ważniejsze było przyjęcie przez rząd oczekiwanej ustawy o amnestii, co z przepełnionych do granic więzień pozwoliło zwolnić 34 tys. osób, w większości byłych żołnierzy skazanych za dezercję lub odmowę wykonania rozkazu. Drugą dobrą wiadomością dla zmęczonego wojną społeczeństwa było zniesienie przez ustępującego z urzędu Billa Clintona dotkliwych sankcji gospodarczych, tyczących wspólnego (dualnego) organizmu.

W opcję „kalemegdańską” wpisywali się na pewno w styczniu $2001 \mathrm{r}$. unijni ministrowie spraw zagranicznych przekazując opinię, że Czarnogóra ${ }^{7}$ powinna pozostać w federacji i nie podejmować samodzielnie żadnych akcji, co nerwowo odebrano nad Zeta. Nie mniejszy był sceptycyzm V. Koštunicy po spotkaniu z prokurator Międzynarodowego Trybunału Karnego dla byłej Jugosławii (ICTY) na temat przekazania Slobodana Miloševicia: ,jeżeli ktoś chce zdestabilizować sytuację w kraju - ironizował - to powinien się zachowywać jak Carla del Ponte"s. Jako rzecz zdecydowanie złą potraktowano też pod Avalą oświadczenie

${ }^{4}$ Zob. H. Batowski, Podstawy kryzysu jugosłowiańskiego (konflikt chorwacko-serbski). Odczyt wygłoszony na zebraniu publicznym Polskiej Akademii Umiejętności 16 listopada 1991, odbitka z „Rocznika PAU” 1991-1993, Kraków 1993, s. 22.

${ }^{5}$ Wcześniej M. Đukanović, pozyskany u schyłku lat 80. przez S. Miloševicia w ramach tzw. rewolucji antybiurokratycznej, desygnowany „na odcinek priorytetowych zadań partii” utożsamiał się w pełni z celami kierowanych z Belgradu działań siłowych.

${ }^{6}$ Wypowiedź V. Koštunicy dla Serbskiej Agencji Prasowej, SANA Službeni Bilten, Beograd, 11 januar 2001 godine.

${ }^{7} \mathrm{~W}$ tym tonie wypowiadał się jeszcze w czerwcu 1999 r. bawiący z wizytą dyplomatyczną w Warszawie sam M. Đukanović.

${ }^{8}$ Więcej zob. W. Walkiewicz, Jugostawia. Państwa sukcesyjne, Warszawa 2009, s. 312. 
komisarza Chrisa Pattena, że „Unii, mimo wszystko, przyjdzie zaakceptować wyniki referendum $\mathrm{w}$ sprawie niepodległości, jeśli na takie zadecydują się w Czarnogórze"'.

W lutym 2001 r. zbiegły się peregrynacje do Waszyngtonu: M. Đukanovicia - z jednej, oraz albańskich antenatów Ibrahima Rugovy: Hishima Thaçiego i Vetona Surroi - z drugiej strony. Pierwszy zamierzał przekonywać do racji „niepodległej i samostanowiącej” Czarnogóry, pozostali dyskutowali z sekretarzem stanu Colinem Powellem kwestie statusu Kosowa. Zaraz potem za ocean poleciał Zoran Đinđić, by zabiegać nad Potomakiem o tamtejsze wsparcie dla apelu o pomoc materialną dla kraju uzależnionego od społeczności międzynarodowej ${ }^{10}$.

Znalezienie w belgradzkiej willi martwego Zorana Sokolovicia, byłego ministra spraw wewnętrznych Jugosławii (do 2000 r.), aresztowanie siedmiu wysokich funkcjonariuszy poprzedniej ekipy czy nieudany zamach na szefa resortu spraw wewnętrznych Serbii Dušana Mihailovicia odsuwało w cień wizytę Vojislava Šešelja, lidera radykałów, w Bagdadzie, gdzie „w atmosferze zrozumienia" ${ }^{11}$ konferował z Saddamem Husseinem, a nawet - premiera Federacji Rosyjskiej Michaiła Kasjanowa, który przybył w sprawie warunków pożyczki, na jaką przystał Kreml.

Pod koniec zimy wprowadzono posterunki celne na granicy Serbii i Czarnogóry. Prezydent tej ostatniej zapowiedział, że wybory do parlamentu odbędą się 22 kwietnia 2001 r., a czarnogórski minister spraw zagranicznych Branko Lukovac $^{12}$ przypominał, iż Belgrad nie ma prawa reprezentować republiki na arenie międzynarodowej. Na wiecu z okazji rozpoczęcia kampanii M. Đukanović wywodził, iż niepodległość „całkowita i niepodzielna” jest niezbędnym warunkiem dokończenia reform. Po drugiej stronie osi problemów boleśnie odbierano narastająca przemoc albańską w Kosowie, gdzie np. w zamachu na autokar niedaleko Podujeva zginęło 10, a rannych zostało 40 Serbów. Oficjalna Podgorica solidaryzowała się z V. Koštunicą w krytykowaniu Sojuszu Północnoatlantyckiego za ,popieranie idei Wielkiej Albanii oraz podsycanie terroryzmu"13.

1 kwietnia 2001 r. nad ranem, w Belgradzie dokonano zatrzymania S. Miloševicia, który przegrał we wrześniowych wyborach $2000 \mathrm{r}$. Władze próbowały studzić emocje prześcigając się w oświadczeniach, że ten do niedawna „mąż opatrznościowy” sądzony będzie w ojczyźnie, „gdyż nie ma podstaw prawnych

9 Tamize.

10 Tamże. Uzyskana pomoc wyniosła 260 mln dolarów (w trzech transzach) korzystnego dla Belgradu kredytu.

${ }^{11} \mathrm{Z}$ wypowiedzi V. Šešelja dla popołudniówki „Vecerne novosti”, Beograd 26 april 2001.

${ }^{12}$ Lukovac po secesji pełnił funkcję ambasadora (pierwszego) Czarnogóry w Chorwacji.

${ }^{13}$ W. Walkiewicz, dz. cyt., s. 313. 
do jego ekstradycji” ${ }^{\prime 4}$. Aresztowanie spotkało się z pozytywną reakcją opinii światowej, a George W. Bush wyraził przekonanie, że będzie ono „ważnym krokiem do sądzenia za zbrodnie przeciwko ludzkości” ${ }^{15}$. Na potrzeby wewnętrzne V. Koštunicy pozostawało upierać się przy konstrukcji, iż ekstradycja do Hagi „nie powinna mieć miejsca” $i$ „nikt nie ma prawa w tym celu czynić nacisków”'

Trzy tygodnie później w wyborach parlamentarnych ${ }^{17}$, przy imponującej $82 \%$ frekwencji, partia M. Đukanovicia „Zwycięstwo Czarnogóry” otrzymała $42 \%$ głosów i 36 (na 77) miejsc w parlamencie Czarnogóry. Opozycyjny blok „Razem dla Jugosławii” zyskał poparcie blisko 41\% przybyłych do urn i zdobył 33 mandaty, a Liberalny Sojusz Czarnogóry zagospodarował prawie 8\% głosów (6 poselskich foteli). W świetle wyraźnego radykalizowania się postaw secesyjnych do dialogu na temat przyszłości wspólnego państwa wezwała Serbię i Czarnogórę najpierw administracja Białego Domu, a zaraz potem $\mathrm{w}$ taki sam ton uderzyli funkcjonariusze Unii Europejskiej (UE). W czasie rozmów w Podgoricy przedstawiciele Brukseli ostrzegali przed „unilateralnymi” i „gwałtownymi” ruchami w kierunku „niezawisłości, która okazać się może mocno odseparowana" ${ }^{18}$. Prezydent odrzucał supozycje podkreślając, iż ani parlament, ani rząd Filipa Vujanovicia, „ani on sam”, nie zamierzają zmieniać dotychczasowej strategii w tej sprawie oraz że ostatecznym celem politycznego kursu jest nie co innego, jak stworzenie warunków integracji ze strukturami europejskimi ${ }^{19}$. Skonfundowani takim dictum unijni peacemakerzy salwowali się „konsultacjami” z przedstawicielami bloku „Razem dla Jugosławii”, którzy poza utwierdzeniem $\mathrm{w}$ woli zachowania federacji, wyposażyli ich w oskarżenie, iż w czasie wyścigu do zgromadzenia doszło do „nieprawidłowości” ${ }^{20}$, bez których kompozycja tego ciała nie musiałaby być „jaka jest”.

Nie bez wpływu na optykę czarnogórską pozostawał bieg spraw w Prisztinie, gdzie w huku eksplodujących min, cywilny administrator Hans Haekkerup ogłosił, iż nowe Zgromadzenie powinno zostać tam sformowane nie później niż do końca $2001 \mathrm{r}$. W swoistej kontrodezwie, belgradzki sztab generalny spieszył „donieść”, że panuje nad bezpieczeństwem, a prokuratura zakończyła właśnie postępowanie wobec 183 żołnierzy ${ }^{21}$. Synchronicznie - Skupsztina Federalna

${ }^{14} \mathrm{~W}$ wypowiedziach tego typu celowali nacjonaliści i socjaliści z formacji kierowanej przez... Mirę Marković, żonę S. Miloševicia.

${ }^{15} \mathrm{~W}$ podobnym tonie wypowiedział się również m.in. niemiecki minister spraw zagranicznych Joschka Fischer.

16 Tamize, s. 314.

17 Wybory odbyły się 22 kwietnia 2001 r.

${ }_{18}$ Wobec ubóstwa literatury nt. wydarzeń politycznych najnowszych tamże, nieocenioną pozycją pozostaje monografia F. Šistek, Černa Hora, Praha 2007.

${ }^{19}$ Więcej zob.: M.S. Lopušina, Milo. Jedna evropska priča, Niš-Beograd 2005.

${ }^{20} \mathrm{Z}$ perspektywy czasu wydaje się, że supozycje takie nie były bezpodstawne: przebieg wyborów mógł wpłynąć na wynik głosowania.

${ }^{21}$ Chodziło o przewinienia, a w kilku przypadkach zarzuty dopuszczenia się czynów 
przyjęła uchwałę, w której domagano się większych praw dla Serbów i innych zamieszkujących prowincję niealbańskich mniejszości.

Indagowane przez V. Koštunicę w kwestii przesunięcia ustalonych w Brukseli na 17 listopada wyborów w Kosowie, Ministerstwo Spraw Zagranicznych Federacji Rosyjskiej wydało oświadczenie, w którym skrytykowało popieranie przez Administratora „drogi wiodącej, de facto, do referendum”. Metodę „kija i marchewki” egzemplifikowało ćwierć mld dolarów pożyczki udzielonej czerwcu Serbii przez Międzynarodowy Fundusz Walutowy, która „zbiegła się” z aresztowaniem Borislava Milacicia, ministra finansów za czasów S. Miloševicia ${ }^{22}$. Półrocze zamykało zezwolenie NATO na wprowadzenie oddziałów jugosłowiańskich do strefy zdemilitaryzowanej na granicy z Kosowem, podpisanie umowy z Bośnią o powołaniu Wspólnej Rady na Rzecz Poprawy Wzajemnych Stosunków, w obszarze niniejszych rozważań - powierzenie podgorickiemu premierowi misji głębokiego zrekonstruowania gabinetu ${ }^{23}$.

Wydanie S. Miloševicia 28 czerwca 2001 r. ICTY spotkało się z pozytywnymi komentarzami państw zachodnich i krytyką ze strony Rosji. Ekstradycja sprawiła, że już dzień później obradować mogła konferencja darczyńców w sprawie pomocy, podczas której zobowiązano się udzielić federacji pożyczek w wysokości 3,9 mld dolarów w ciagu trzech lat, w tym blisko 1,3 mld do końca 2001 r. ${ }^{24}$

9 sierpnia F. Vujanović obwieścił, iż referendum w sprawie statusu (czytaj: oderwania) państwa odbędzie się w marcu 2002 r., by w urodzie rotacyjnego mechanizmu, osiem dni później, Dragiša Pešić z tamtejszej (czytaj: serbskiej w Czarnogórze) Socjalistycznej Partii Ludowej został szefem nowego rządu... Jugosławii ${ }^{25}$. Nie gasły polityczne namiętności w Wojwodinie, gdzie liderzy 14 partii i organizacji pozarządowych zbudowali wspólną platformę, domagając się „pełnej autonomii” dla prowincji ${ }^{26}$. Dla federacji in corpore dobra decyzją było zniesienie 10 września embarga na handel bronia, dobra, którego w odróżnieniu od innych akurat w spadku po „regionalnej sile” nie brakowało. Wbrew woli przedstawicieli Czarnogóry, którzy jesienią zbojkotowali zaplanowane spotkanie z reprezentantami władz serbskich przygotowywane dla omówienia statusu obu państw. Powodem była - jak tłumaczono - obecność w „roboczej komisji”

karalnych w czasie wydarzeń kosowskich w latach 1998-1999.

${ }^{22} \mathrm{Na}$ ten temat zob. W. Walkiewicz, dz. cyt., s. 316.

${ }^{23}$ Dla gremium serbsko-czarnogórskiego nie bez znaczenia była też wizyta prezydenta Federacji Rosyjskiej w Belgradzie.

${ }^{24}$ Tamże, s. 316 i n.

${ }_{25}$ Obie daty przedzielał jedynie dekret, jakim rodzina królewska Karađorđeviciów odzyskała swoje rezydencje w Belgradzie.

${ }^{26}$ Więcej zob.: A. Jagiełło-Szostak, Dażenia Vojvodiny do autonomii - nowy separatyzm w Europie?, [w:] Bezpieczna Europa z perspektywy Wschodu, red. W. Walkiewicz, Warszawa 2010. 
premiera D. Pešicia, cokolwiek by nie mówić ich krajana, tyle tylko, że żarliwego zwolennika „braterstwa i jedności”’7.

W Belgradzie, gdzie 5 października 2001 r., w rocznicę obalenia anciem regime'u 200 tys. manifestantów wyrażało zadowolenie $\mathrm{z}$ „usunięcia dyktatora”, rozpoczą się proces Radomira Markovicia, szefa jego tajnej policji. Podczas gdy emerytowany gen. Pavle Strugar dobrowolnie oddał się do dyspozycji ICTY, prokurator Del Ponte, podejmowana przez Z. Đinđicia, starała się wyegzekwować aresztowanie osób „odpowiedzialnych za niszczenie Dubrownika i Vukovaru”, co siłą rzeczy niepokoić musiało uczestniczących w ostrzałach tego pierwszego żołnierzy czarnogórskich i ich rodziny.

Tymczasem serbski wicepremier Nebojša Čović złożył podpis pod umową z H. Haekkerupem, która zakładała, że nowy parlament Kosowa nie może ogłosić niepodległości prowincji. Na stołeczne ulice wyszli socjaliści, jako pretekst do demonstracji wykorzystując komunikat, że prokuratura wszczęła śledztwo przeciwko M. Marković, żonie byłego prezydenta Miloševicia. Synchronicznie dała znać o sobie także opozycja nad Moračą i Pivą bojkotując obrady krajowego parlamentu. Najgłośniej artykułowanym powodem były pomówienia i „realne oskarżenia” wobec „Milo”28 o związki z (włoska) mafią papierosową i nie tylko nagłaśniane zwłaszcza przez ,wolne” media chorwackie.

W wyborach w Kosowie Liga Demokratyczna zdobyła 46\% głosów i 47 miejsc, podczas gdy ugrupowanie H. Thaçiego uzyskało $26 \%$ głosów i 26 mandatów. Serbski „Povratak” otrzymał 11\% głosów i 22 miejsca, Sojusz dla Przyszłości (8\% i tyleż foteli). „Sukcesu” nie omieszkał dyskontować na rzecz Brukseli, wyraźnie tracacej dystans do USA w kreowaniu nowego państwa albańskiego, Javier Solana, głoszący wszem wobec, iż jest to „decydujacy krok w rozwoju demokracji”"

Belgrad przypomniał się u schyłku roku 2001 r. rezygnacją (6 grudnia) Dragana Maršičanina z funkcji przewodniczącego serbskiego parlamentu głownie wskutek konfliktu z posłami z Partii Demokratycznej. Termin zbiegł się z inauguracyjnym posiedzeniem Zgromadzenia w Prisztinie, gdzie, wobec fiaska rozmów koalicyjnych, Liga powołała rząd mniejszościowy... 9 grudnia. Rugova - pretendent na najwyższy z urzędów - nie został wybrany, za sprawą bojkotu deputowanych ugrupowania „Powrót” ${ }^{30}$.

${ }_{27}$ W. Walkiewicz, dz. cyt., s. 316.

${ }^{28}$ Interesujące studium, zbudowane wokół postaci M. Đukanovicia i jego obozu przedstawia W. Szczepański, Gtówne problemy polityczne jugostowiańskiej Republiki Czarnogóry w okresie od kwietnia 1992 r. do marca 1999 r., [w:] Batkany w XX i XXI wieku. Historia - polityka - kultura. Materiały z konferencji „Poznać Bałkany”. Toruń, 29 maja 2009 roku, pod red. H. Stysa i Sz. Sochackiego, Toruń 2009.

${ }^{29}$ W. Walkiewicz, dz. cyt., s. 319.

${ }_{30}$ Problem secesji byłego okręgu autonomicznego i prisztinskiej sceny politycznej udanie omawia K. Pawłowski, Kosowo. Konflikt i interwencja, Lublin 2008. 
Nim nadeszła zima, u zbiegu Sawy i Dunaju rozpoczęły się rozmowy między delegacjami Serbii i Czarnogóry na temat wzajemnych stosunków obu państw. W morzu różnic i stanowisk wzajemnie się wykluczających osiagnięto jedno, tj. zgodę w sprawie ustanowienia komisji ekspertów, która miała ocenić wstępne, w tym ad hoc modyfikowane propozycje stron. Czy można się było dziwić, że w środku tej procedury apel Podgoricy do Rady Europy o nieprzyjmowanie Jugosławii do swego grona wywołał tam irytację. 0 niełatwym politycznym „chlebie” na Bałkanach, zwłaszcza w przypadku osób nawykłych do norm europejskich, przekonał obserwatorów trzy dni przed końcem roku H. Haekkerup, rezygnując z funkcji bez podania powodów, jakkolwiek spekulowano, iż były nimi amnestie dla Kosowarów winnych zabójstw oraz problemy we współpracy z tamtejszymi liderami ${ }^{31}$.

W sylwestrową noc (2001/2002) euro zostało legalną walutą Czarnogóry ${ }^{32}$, zastępując wycofaną z obiegu niemiecką markę (i uniezależniając się przynajmniej po części od serbskiej hiperinflacji). Na przeciwległym krańcu „sfederowanych posiadłości" rok zaczął się od krwawego zamachu bombowego (śmierć poniosło kilkanaście osób) na restaurację w Wojwodinie, gdzie świętowano (prawosławne) Boże Narodzenie. Nie szukano tu poszlak muzułmańskiego „śladu”. Tym samym, 10 stycznia 2002 r., w dniu, w którym nie powiodła się próba większości albańskiej wyłonienia prezydenta, M. Đukanović ogłosił, iż referendum w sprawie niepodległości odbędzie się „w kwietniu lub maju” 2004 r.

Luty zaczął się przyjęciem wraz z rozpoczęciem przez parlament Serbii pakietu ustaw gwarantujących prawa autonomiczne dla Wojwodiny. Podczas gdy przedstawiciele tej prowincji uznali to za „za pierwszy krok do nadania większych uprawnien”, kilka tysięcy „synów orłów”, wojowniczo protestowało w Prisztinie, domagając się zwolnienia rodaków oskarżonych o zbrodnie, aresztowanych przez siły $\mathrm{KFOR}^{33}$. W „trzecim obszarze” J. Solana w rozmowach z przedstawicielami Serbii i Czarnogóry „obstawiał” architekturę federalna, krytykując tendencje wiodące ku podziałowi Jugosławii, co Podgoricy podobać się nie mogło.

$\mathrm{W}$ połowie miesiąca, z rozpoczęciem procesu S. Miloševicia, przeciwko któremu wytoczono 66 oskarżeń, w tym o ludobójstwo, M. Đukanović zakomunikował, iż referendum w sprawie niepodległości nie może się niestety odbyć $\mathrm{w}$ planowanym terminie ${ }^{34}$. Komentatorzy odczytali to jako ugięcie się pod presją

31 Więcej zob. W. Walkiewicz, dz. cyt., s. 315-320.

32 Jesienią 1999 r. Czarnogóra wprowadziła walutę niemiecką do równoległego obrotu z niestabilnym dinarem jugosłowiańskim, jednakże już w roku następnym za jedyny środek płatniczy w republice uznano markę pozwalającą na „odcięcie się” od federalnej zapaści, skutkującej dramatycznie niskim poziomem PKB (nad Zetą za 1999 r. wyniósł on per capita niespełna 1,1 tys. dolarów).

${ }^{33}$ Kosovo's Fragile Transition, „Europe Raport” no. 97, International Crisis Group, February 2004.

${ }^{34}$ Zwłokę udanie przekuwały w cnotę „dojrzałej politycznej strategii” podgorickie 
UE, która niedwuznacznie sugerowała, że Serbia i Czarnogóra powinny pozostać „w jednym państwie”. Ostatecznie, obok argumentów „pomocowych”, pułap modyfikacji w sprawie przyszłości fuzji jugosłowiańskiej zdynamizować miał opracowany w Brukseli plan utrzymania obu „składowych” w luźnej federacji bez „Zwierzchniej czapki” ${ }^{\prime 3}$.

14 marca 2002 r. przedstawiciele Serbii, Czarnogóry i Jugosławii oddzielnie podpisali umowę w sprawie kształtu wzajemnych stosunków. Zmianie uległa nazwa państwa - zastapiła ją konstrukcja dualna: „Serbia i Czarnogóra”. Dotychczasowy prezydent zachował swą funkcję, a nowy twór nie zwiększał reprezentacji w ONZ. Powtarzając za V. Koštunica ,nie była to federacja ani konfederacja, ale raczej coś nowego" ${ }^{36}$. Podgorica zobowiązała się do nierozpisywania referendum w sprawie niezawisłości w ciagu najbliższych co najmniej trzech lat. Elity polityczne układajacych się stron w większości wyraziły uznanie dla osiagniętego kompromisu. Porozumienie poparła również UE, co więcej uznanie wyraziły też inne republiki postjugosłowiańskie, a także Waszyngton. Nie oznaczało to jednak i braku krytyki, zwłaszcza ze strony niektórych serbskich polityków o orientacji nacjonalistycznej oraz Liberalnego Sojuszu Czarnogóry. Premier Kosowa Bajrem Rexhepi potraktował wydarzenie w kategoriach „brzemienia przeszłości”, stwierdzając zdecydowanie, iż nie zmieni to niepodległościowych dążeń prowincji albańskiej.

Wkrótce społeczeństwo przekonać się miało, że strajk około 30 tys. pracowników kolei, domagających się wzrostu płac, paraliżuje życie skutecznie, to zaś pełne jest zdziwień, zważywszy, że wicepremier Serbii Momčilo Perišić podał się do dymisji w związku z oskarżeniami o działalność wywiadowczą... na rzecz Stanów Zjednoczonych ${ }^{37}$. Jakby tego było mało, Liberalny Sojusz Czarnogóry zapowiedział wycofanie poparcia dla gabinetu F. Vujanovicia w proteście przeciwko porozumieniu o zmianie statusu wspólnego państwa.

W aurze „świętej nocy, kiedy niebo nad Kosowem zostało rozjaśnione światłem nadziei i odnowy" ${ }^{\text {"8 }}$, rząd Serbii jednogłośnie przyjął projekt ustawy

„Vjesti” (prođukanoviciowski dziennik powołany do życia jesienią 1997 r.), inaczej rzecz postrzegali komentatorzy względnie niezależnej Agenciji Montana-fax, Monitora czy Radia Cetinje.

${ }_{35}$ Zob. Ž. Andrijašević, Š. Rastoder, The History of Montenegro, from Ancient Times to 2003, Podgorica 2006.

36 W wywiadzie dla Radia B-92.

${ }^{37}$ Polityk serbski „namierzony” został przez służby specjalne na gorącym uczynku spożywania „na mieście” lunchu (sic!) z dyplomatą amerykańskim.

38 Cytat za afektowanym wystapieniem I. Rugovy, sorbońskiego doktora czy jak zwykł określać się chętniej „bałkańskiego Gandhiego” w drodze do...najwyższego z kosowskich urzędów; nt. rozwoju sytuacji w Kosowie zob.: D.H. Allin, NATO’s Interventions, Oxford 2002; A.J. Bellamy, Kosovo and International Society, New York 2002; R. Dajti, Pas luftës në Kosove, Tiranë 2003. 
ustalającej zasady współpracy z ICTY, a Skupsztiny w Belgradzie i Podgoricy ratyfikowały porozumienie $\mathrm{w}$ sprawie relacji $\mathrm{w}$ ramach wspólnego państwa. Następne dni nie potwierdziły akceptacji dla działań deputowanych: w Czarnogórze głosowanie doprowadziło do kolejnego kryzysu rządowego, natomiast po tym jak kluby opowiedziały się za współdziałaniem z Haga, Vlajko Stojliković, były minister spraw wewnętrznych, popełnił samobójstwo przed gmachem parlamentu. To nie była wiosna dygnitarzy, zważywszy, że np. rzecznik Trybunału goszczący w Nowym Sadzie wydał oświadczenie, iz prezydent Serbii Milan Milutinović jest oskarżany o zbrodnie i wobec tego nie chroni go immunitet, a federalne Ministerstwo Spraw Wewnętrznych przygotowało listę 18 „ważnych osób” oskarżanych o ciężkie przestępstwa wojenne.

Niezgorzej miały się sprawy pomocy finansowej: Międzynarodowy Fundusz Walutowy przyznał Serbii i Czarnogórze pożyczkę w wysokości 825 mln dolarów, płatną przez trzy lata, Z. Đinđić i Goran Svilanović w Waszyngtonie uzyskali od C. Powella zapewnienie wsparcia Stanów Zjednoczonych przy renegocjacji długów z Klubem Paryskim, a Wielka Brytania umorzyła 51\% „starych” należności. Tymczasem koalicja niepodległościowa M. Đukanovicia utrzymała w majowych (2002 r.) wyborach lokalnych dotychczasowy stan posiadania a Skupsztina, rozwiązawszy 22 maja rząd, utworzyła nazajutrz komisję w celu opracowania ustawy zasadniczej ,adekwatnej do nowych warunków współistnienia z Serbią”39.

W czerwcu 2002 r. zastrzelono w Belgradzie gen. Boško Buhę, szefa policyjnych oddziałów prewencji za czasów S. Miloševicia, w Kosowie fetowano rocznicę wkroczenia wojsk NATO, a dla nie podzielających radości Ceca - gwiazda turbo-folku i wdowa po Željko Ražnatoviciu, znanym jako „Arkan” - dała pierwszy po śmierci oprawcy koncert, gromadząc na stadionie Crvenej Zvezdy Belgrad 60 tys. widzów. Parlament Czarnogóry zniósł za to karę śmierci, przyjął ustawę o zwrocie majątku zagrabionego przez komunistów prawowitym właścicielom (oceniony na 1,2 mld dolarów), a tamtejszy Sojusz Liberalny zaproponował utworzenie rządu koalicji „Razem dla Jugosławii”, która miała się przeciwstawić secesji ${ }^{40}$.

W połowie 2002 r. opublikowano wyniki spisu powszechnego w Serbii. Populacja (bez Kosowa) liczyła ok. 7,5 mln osób, tj. ok. 70 tys. mniej niż w 1991 r. Ogłoszono też, że w ciagu najbliższych sześciu miesięcy pensja minimalna zostanie podniesiona do... 63 dolarów! ${ }^{11} \mathrm{~W}$ sierpniu ugrupowania czarnogórskie doszły do porozumienia $\mathrm{w}$ sprawie ordynacji $\mathrm{w}$ wyborach parlamentarnych, przewidzianych na październik. Okolicznością pozytywną dla wszystkich było to, ze Rosja zgodziła się umorzyć $66 \%$ długu należnego jej od nowej „unii”.

Z nastaniem jesieni 2002 r. rozpoczął się drugi etap procesu S. Miloševicia, a w wyborach prezydenckich w Serbii (29 września) zwycięzcą okazał się

\footnotetext{
${ }^{39}$ W. Walkiewicz, dz. cyt., s. 322.

40 Tamże, s. 324-325.

${ }^{41}$ Zob. Statistički godišnjak Republike Srbije, Beograd 2002.
} 
V. Koštunica, który zagospodarował ponad 31\% głosów, przed Miroljubem Labusem, który zgromadził ich blisko 28\%. Zanim przeprowadzono drugą turę, amerykańska Izba Reprezentantów przyjęła ustawę o normalizacji stosunków handlowych z Serbią i Czarnogóra. 13 października największym zaufaniem obdarzono ponownie przywódcę demokratów (cokolwiek miałoby to oznaczać), który otrzymał tym razem ponad 66\% poparcia. Wybory uznano jednak za nieważne, gdyż frekwencja wyniosła jedynie $45,5 \%$ uprawnionych, co sprawiło, że powtórkę przy urnach wyznaczono na 8 grudnia $2002 \mathrm{r}$.

Dylematy nie nękały gremiów partyjnych u sąsiadów: 20 października zwycięzcą okazała się stworzona przez M. Đukanovicia formacja „Demokratyczna Lista dla Europejskiej Czarnogóry”, która uzyskała prawie 45\% głosów i 39 (na 75) miejsc w parlamencie. Koalicja „Razem dla Zmian” przekonała prawie $36 \%$ głosujących, co przełożyło się na 30 mandatów (Sojusz Liberalny wywalczył ich 4, a frekwencja wyniosła wzorowe $77,5 \%$ ). W wystapieniu, transmitowanym przez telewizję, zaraz po ogłoszeniu wstępnych wyników, lider Listy potwierdził kurs niepodległościowy i proeuropejski republiki, a 5 listopada Skupsztina wybrała na swego przewodniczącego F. Vujanovicia, odchodzącego premiera ${ }^{42}$.

Pod koniec miesiąca nieznany sprawca wymierzył sprawiedliwość Nenadowi Batočaninowi, byłemu szefowi ochrony Miloševicia, a w piątym rozdaniu fotel prezydenta Kosowa przypadł w końcu I. Rugovie, terminarz uzupełniało zaś aresztowanie na początku najpierw (w Hiszpanii) obywatela Niemiec Joe Trutschlera, urzędnika UE w Kosowie, za defraudację 4,5 mln dolarów, a potem - za udział w handlu żywym towarem - Zorana Piperovicia, zastępcę prokuratora generalnego Czarnogóry. 6 grudnia 2002 r. Belgrad i Podgorica doszły do porozumienia w sprawie federacji. Końcówkę roku malowały ogólnie barwy spolegliwości i koncyliacji: w delcie Ribnicy i Moračy powołano rząd, którego szefem został (o wiele wcześniej, zanim „patent” taki nazywać zaczęto kremlowskim) eksprezydent M. Đukanović, niższa izba federalnego parlamentu ratyfikowała porozumienie z Dayton, a prezydenci Albanii, Bośni, Chorwacji, Jugosławii i Macedonii wystosowali list do UE, w którym jednym głosem prosili o określenie możliwości integracji z nią. Do atmosfery bożonarodzeniowej dostroili się szef dyplomacji Jugosławii G. Svilanović i sekretarz generalny NATO George Robertson osiagając draft $\mathrm{w}$ sprawie udostępnienia przestrzeni powietrznej samolotom Paktu, za co Stany Zjednoczone uwolniły jugoaktywa zamrożone w tamtejszych bankach od $1992 \mathrm{r}^{43}$

Ku zdziwieniu obserwatorów, czarnogórskie wybory na urząd prezydenta, w których zwycięstwo zapewnił sobie, co nie trudno było przewidzieć, F. Vujanović (86\% głosów), okazały się nieważne, gdyż frekwencja, zwyczajowo przykładna, wyniosła jedynie $46 \%$. Nim gubiacy się w realiach i intencjach dyplomaci udali

${ }_{42}$ Zob. Istorijski leksikon Crne Gore, Podgorica 2006.

${ }^{43}$ W. Walkiewicz, dz. cyt., s. 326. 
się na przyjęcia kończące rok 2002, Nataša Mićić, przewodniczaca parlamentu Serbii, zastapiła na stanowisku prezydenta tejże M. Milutinovicia ${ }^{44}$, orędownika związku „na zawsze” obu krajów.

W referendum niepodległościowym przeprowadzonym w Czarnogórze w maju 2006 r., 55\% bioracych udział opowiedziało się za zerwaniem więzów innych niż sąsiedzkie z Serbia. Zbrojny w tę wolę parlament mógł 3 czerwca proklamować Republikę wolną w swych dążeniach wewnętrznych i orientacjach międzynarodowych. W momencie tak uroczystym, po latach rozwodowej celebry, nie sposób było przydawać wagę temu, że państwu, gdzie korpus narodowy z trudem osiaga 43-procentowy próg identyfikacji, przyjdzie stanać przed trudnym wyzwaniem potwierdzenia woli budowy partnerskich relacji ze światem i demokratycznego ładu pośród 685-tysięcznej populacji.

Już na starcie nie wolne od sporów stały się prace komitetu grupującego przedstawicieli ugrupowań parlamentarnych, mające skutkować propozycja ustawy zasadniczej. Ta wszakże stanowiła w relacjach zagranicznych warunek sine qua non dla osiagnięcia Układu o Stabilizacji i Stowarzyszeniu z UE oraz rozpoczęcia procesu akcesyjnego. Przeszkodę dla uzgodnień stanowił brak zgody liderów co do określenia rzeczonej tożsamości: o ile bowiem socjaliści (DPS) i socjaldemokraci (SDP) widzieli ja jako expressis verbis „czarnogórską, o tyle opozycja serbska przystać na takie dictum nie była gotowa. Poza argumentami wspólnego języka, historii i kultury, w „projekcie większości” dopatrywano się tu artykułowania „uczuć nienawiści” czynników podgorickich wobec niedawnego belgradzkiego centrum.

Dyskurs przybierał na sile wraz ze sporem między serbskim a czarnogórskim Kościołem prawosławnym zarówno o prawa własności do obiektów (sakralnych i towarzyszących), jak i o to, który z nich zyska w konstytucji miano narodowego. W kwestii uzgodnień co do przedmiotowej delegacji w treści samej ustawy blisko połowa populacji zdawała się przychylać do idei referendum ${ }^{45}$. Chociaż jednak prawie 1/3 cedowała decyzję na Skupsztinę, to równocześnie panowała dość powszechna opinia o równoprawności czarnogórskiego i serbskiego jako języków urzędowych.

Przeprowadzone wiosną $2008 \mathrm{r}$. wybory prezydenckie, zakończone reelekcja F. Vujanovicia, odczytywano jako dowód akceptacji dotychczasowych poczynań lewicowej koalicji (DPS-SDP), w tym zdecydowanej postawy w kwestii ochrony cerkwi, monasterów i innych dóbr przed roszczeniami autokefalii serbskiej. Oliwy do ognia dolało nieprzepuszczenie przez miejscowe służby graniczne na

${ }^{44}$ Były minister spraw zagranicznych Jugosławii, premier, a następnie prezydent republiki udał się dobrowolnie do Hagi, gdzie sądzony był przez ICTY.

45 Według badań przeprowadzonych wiosną przez amerykański Instytut Badań nad Demokracją (US ONDI) 4/5 respondentów było zdania, że państwo winno być zdefiniowane jako „społeczność obywateli”. 
początku lipca 2007 r. jej reprezentanta - biskupa Filareta. W trzy tygodnie później premier Željko Šturanović, który jesienią 2006 r. zastapił uwikłanego w różne „biznesy” M. Đukanovicia, poinformował, że zakaz wjazdu dostojnika wydany został na życzenie Brukseli, z powodu jego roli w udzielaniu pomocy osobom ściganym za zbrodnie wojenne ${ }^{46}$.

Echem szerszym niż głodowy protest duchownego przeprowadzony w rozbitym przezeń obozowisku i słanie stamtąd not protestacyjnych, odbiło się wysadzenie 10 sierpnia przez tzw. nieznanych sprawców wznoszonego tu obiektu „ortodoksji sąsiedniej”. Niezależnie od tego, czy był to - jak chcieli belgradzcy hierarchowie - „akt terrorystyczny”, czy też przedsięwzięcie „nieskoordynowane”, szermowała nim sowicie najliczebniejsza spośród ugrupowań serbskich - Partia Ludowa. U źródeł nabrzmiewających, mimo „aksamitnego podziału”, waśni leżała z jednej strony troska o zbudowanie poczucia odrębności, wyposażonej w możliwie najszerszy wachlarz cech identyfikacyjnych, z drugiej zaś batalia o uznanie wspólnej tradycji. Siłą rzeczy przyczyniło się to do ochłodzenia stosunków między niedawnymi „federatami” w stopniu na tyle niepokojącym, że w misję przezwyciężenia kryzysu zaangażował się osobiście J. Solana.

Próby powrotu na ścieżkę dialogu (m.in. list szefa dyplomacji Serbii Vuka Jeremicia przepraszający za niestosowne treści niektórych wypowiedzi ${ }^{47}$ członków gabinetu, zgoda na wizytację Filareta i in.) zakończyły się niepowodzeniem. Na domiar złego Skupsztina nad Dunajem przyjęła 24 września 2007 r. uchwałę dająca prawo ubiegania się o obywatelstwo macierzy przez wszystkich zamieszkujących poza granicami rodaków, co Czarnogórcy odczytali jako zniewagę dla swojej suwerenności, zapowiadając, że chcących z opcji tej skorzystać traktować będą jak cudzoziemców.

Atmosfera oskarżeń nie sprzyjała niwelowaniu różnic w stanowiskach koalicji rządzącej i serbskiej opozycji, a przystanie na wznowienie rozmów nad kształtem konstytucji w połowie września nie przyniosło rezultatu. Trzeba było kolejnej wersji ustawy, by 15 października posłowie w sile $2 / 3$ zechcieli ją zaaprobować, a niespełna tydzień później, mimo protestów czterech ugrupowań serbskich $^{48}$, uroczyście przyjąc ${ }^{49}$. Eksplorująca z dorobku dojrzałych demokracji europejskich wyrażała ona kwintesencję celów nowo nastałej samodzielności, definiujac zasady ustrojowe (m.in. system prezydencko-parlamentarny czy dwuizbowość Zgromadzenia).

${ }_{46}$ Pomocy takiej miał ze strony serbskiej Cerkwi uświadczyć m.in. gen. Ratko Mladić.

${ }^{47} \mathrm{~Np}$. doradca premiera Aleksandar Simić określił Czarnogórę jako quasi-państwo, a minister infrastruktury Velimir Ilić opatrzył odwołanie w nim swojej wizyty komentarzem pełnym inwektyw.

48 Były to: Lista Serbska (SL), Demokratyczna Partia Serbska (DDS), Socjalistyczna Partia Ludowa (SNP) i wspominana wcześniej Partia Ludowa (NS).

${ }^{49}$ Oficjalnie parlament przyjął nową konstytucję 19 października 2007 r. 
Dokument potwierdzał obowiązujace urządzenie wewnętrzne, prawa obywateli, w tym mniejszości narodowych, rozdział religii od państwa, hymn, flagę. $32 \%$ ogółu społeczeństwa uważało go za antyserbski, a Albańczycy, których doliczono się ok. 6\%, wołali na larum, obawy wyrażała 8-procentowa populacja Bośniaków ${ }^{50}$. Nim konstytucja zagościła w realiach, kraj przyjąć zdążono w maju 2007 r. do Rady Europy, a w ważnym w tej części Bałkanów dniu 28 czerwca 2006 r. do Organizacji Narodów Zjednoczonych. Pośród wielu trosk społeczeństwa, które w $64 \%$ przyjmowało za swój język serbski, a tylko w 22 czarnogórski (zadekretowany literą konstytucji jako oficjalny, narodowy), zwolna pokonywano kolejne bariery, jak $\mathrm{np}$. tworzenie gwarancji socjalnych. Wśród priorytetów wymieniano skoncentrowanie się na procesach akcesyjnych, wskazywano pilna potrzebę harmonizacji prawa z normami obowiąujacymi w UE, co wymagało przeprowadzenia zmian legislacyjnych.

Już w pierwszym roku suwerenności Czarnogóra odnotowała postępy w kwestii przemian gospodarczych, napływu kapitału inwestycyjnego (na poziomie $900 \mathrm{mln}$ euro), rozwoju sektora prywatnego, turystyki czy bankowości. Rozpoczęto szereg zalecanych przez Brukselę reform, zapowiedziano walkę z korupcja, stosunkowo dobrze radzono sobie z łagodzeniem napięć, umiejętnie unikając ich także na płaszczyźnie zewnętrznej. W realiach bliskosasiedzkich ustanowiono stosunki dyplomatyczne z Serbia, zdobyto się na powściagliwość wobec irredenty kosowskiej, przeprosiny i deklarację odszkodowania względem Chorwacji za szkody wyrządzone tam działaniami wojennymi. Ubiegająca się o członkostwa w Unii Podgorica ukonstytuowała Sekretariat ds. Integracji Europejskiej, powierzając go bezpośrednio wicepremierowi, przyjęła też program działań na rzecz harmonizacji ustawodawstwa.

Dla części analityków mocnym akordem na starcie do wyzwań na początku „wolności” Czarnogóry była rezygnacja Ž. Šturanovicia (w ostatnim dniu stycznia 2008 r.) z pełnionej przez niego przez 14 miesięcy funkcji premiera ${ }^{51}$, co kazało... prosić M. Đukanovicia, by zechciał „poprowadzić” rząd raz kolejny. Politykę wewnętrzną zdominowały jednak przygotowania do wyborów prezydenckich. Choć opozycja wystawiła trzech kontrkandydatów, od początku faworyt był jeden, i - jak nie trudno się domyśleć - był nim F. Vujanović.

Czy zawierzenie nawy państwowej temu tandemowi poniekąd na stałe, to wynik wyrozumowania, układu, braku alternatywy, niechęci do zmian czy wymiernego powodzenia? Ich matecznik - Demokratyczna Partia Socjalistyczna wywodząca się bezpośrednio z czarnogórskiego oddziału Związku Komunistów Jugosławii (SKJ) rozwiązanego w 1991 r., w doświadczenie takie wyposażał.

${ }^{50}$ Według danych spisowych z 2003 r. Czarnogórę zamieszkiwało: 43,2\% Czarnogórców, 32\% Serbów, 11,8\% Muzułmanów (według najnowszej nomenklatury Boszniaków), 5\% Albańczyków, 1\% Chorwatów. Dane za F. Šisek, dz. cyt., s. 111-112.

51 Jako powód podawano zły stan zdrowia tego niespełna 50-letniego polityka, wśród diagnoz wymieniano chorobę nowotworową. 
Czyż po rozpadzie Socjalistycznej Federacyjnej Republiki Jugosławii, od 1991 aż do 1998 r. formacji tej nie przewodził z powodzeniem Momir Bulatović, pozostający w bardzo bliskich stosunkach z Belgradem? Logiczne, że kierownictwo objął po nim M. Đukanović, od szkoły średniej fan i janczar SKJ, sojusznik S. Miloševicia, który w 1991 r. posłał oddziały stacjonujące w Czarnogórze do oblegania Dubrownika. Tak samo jak to, że w $1996 \mathrm{r}$. odciął się od słabnącego protektora, a gdy rozpoczęły się naloty NATO na Jugosławię, otworzył granice dla tysięcy albańskich uchodźców ${ }^{52}$. Za sprawą nieprzeciętnego instynktu, kilka lat później dawny koszykarz, urodzony geszefciarz i partyjny demagog ${ }^{53}$, człowiek-instytucja, stał się zwolennikiem i głównym architektem rozwodu z Serbią i ogłoszenia niepodległości.

Nie inaczej rzecz miała się z F. Vujanoviciem, wykształconym w Belgradzie „apolitycznym” prawnikiem, który w 1993 r. raczył wzmocnić szeregi „nowych socjalistów”, a akces ten M. Đukanović nagrodził natychmiast funkcją ministra sprawiedliwości w swoim rządzie. Kiedy cztery lata później w DPS doszło do konfliktu o przywództwo, w efekcie którego na drodze do fotela prezydenta stanać usiłował dawny stronnik M. Bulatović ${ }^{54}$, premier rozstrzygnał dysonanse na swoją korzyść m.in. dzięki poparciu „protegowanego mecenasa”. ${ }^{\text {. }}$. Stało się to wprawdzie w drugiej rundzie, a opozycja zarzucała fałszerstwa „przy urnach”, któż jednak sądzi zwycięzców. W listopadzie 2002 r. popularny „Milo” zrezygnował z najwyższego urzędu, by znów mógł stanąć na czele rządu F. Vujanović. $\mathrm{W}$ czasie jego prezydentury... kierował on gabinetem, teraz miał go zaś ,na czas techniczny" zastapić w pałacu. Kilka tygodni później wygrał wybory, zdobywając $86 \%$ poparcia (!), ale z powodu frekwencji sytuującej się poniżej progu $50 \%$, głosowanie trzeba było powtórzyć. Powtórkę z demokracji doskonalono z podobnym skutkiem w lutym, by 11 maja 2003 r. z poparciem 63\% elektoratu zmianę warty ostatecznie urzeczywistnic ${ }^{57}$.

Pięć lat później, w kwietniu 2008 r., F. Vujanović sukces powtórzył, tym razem w pierwszej turze, z 52\% głosów przy rekordowej, bo blisko 70\% frekwencji. Wyborców zjednał sobie zarówno proeuropejskim programem, stabilizowaniem sceny, fraternizowaniem się z tłumem podczas każdego z mnogich mitingów. Szermował hasłem „Bez dylematów”, a poparły go m.in. Chorwacka

${ }^{52}$ UE i USA zrewanżowały się za to poparciem dla M. Đukanovicia, szansy na pozytywną rolę tego polityka w procesie reform upatrywano i w Alei Szucha.

${ }^{53}$ Syn komunistycznego działacza został premierem w 1991 r., tzn. w wieku 29 lat. Wzorem karier działaczy z młodzieżowego zaplecza komunistycznej awangardy w krajach realnego socjalizmu - było to jego pierwsze zajęcie „poza komitetem”.

${ }^{54}$ W latach 1990-1998 prezydent Czarnogóry i były premier Jugosławii.

${ }_{55}$ Gwoli prawdzie także dzięki pozyskaniu liberałów Novaka Kilibardy, poparciu ludności albańskiej i sektora biznesu.

56 Zostając 15 stycznia 1998 r. zaprzysiężonym na urzędzie prezydenta.

${ }^{57}$ Szczegółowe studium biograficzne przedstawia M.S. Lopušina, $d z$. cyt. 
Inicjatywa Obywatelska, Demokratyczna Unia Albańczyków oraz ruch reprezentujący bośniackich Muzułmanów. Drugie miejsce (i 30\% głosów) przypadło Andriji Mandiciowi z Serbskiej Partii Ludowej (SNS), reprezentującemu koalicję (listę) mniejszości, zapewniającemu w kampanii, że „Czarnogóra pozostaje nadal serbskim państwem”, krytykującemu dążenie do członkostwa w NATO. Trzecią pozycję - z 17\% poparciem - elektorat zapewnił Nebojšy Medojeviciowi z Ruchu na rzecz Zmian (PZP), ugrupowania technokratów, stawiajacych na program szybkiej integracji z Unią zbytnio jednak jak na czarnogórskie realia „gotującemu się do walki” z korupcją oraz przestępczością zorganizowaną ${ }^{58}$.

Zwycięstwo umocniło i tak bardzo silną pozycję demokrato-socjalistów, obsadzających w „demokratycznej” rotacji bynajmniej nie tylko urzędy i funkcje najważniejsze, ale i synekury w tzw. terenie. Czy jest coś osobliwego w tym, że ugrupowanie „Bez alternatywy” jest w stanie rządzić krajem nieprzerwanie 20 lat? Czy fakt, że w marcu 2008 r. eksprezydent, który dorobił się kilkunastu milionów dolarów, był przesłuchiwany przez prokuraturę z włoskiego Bari, miał go dyskredytować? W końcu nie były to pierwsze oskarżenia: o powiązania, m.in. z camorra, był posądzony przez media od dawna (podobnie jak o nepotyzm, kontakty z oligarchami itd.), włoski wymiar sprawiedliwości wydał nań nakaz aresztowania już w 2004 r., nieskuteczny wobec immunitetu. Czy społeczeństwo na dorobku stać na desygnowanie ciagle nowych, muszacych dorabiać się, partyjnych bossów czy wysokich państwowych urzędników? I czy przykład fortun zbijanych przez ościennych, „poświęcających się dla sprawy” dygnitarzy w Zagrzebiu, Prisztinie czy Sarajewie, Czarnogórcom nie może wyznaczać standardu? Nie oznacza to, by nie dyskutowano tam namiętnie o majątku i interesach osób publicznych, z drugiej strony, czy lepsza mogła być rekomendacja banku nazywanego Prvim (mimo że w istocie drugim w rankingu), w którym szef rządu z siostrą Aną i znacznie zamożniejszym od siebie bratem Aco maja, najlegalniej w świecie, większościowy udział?

Pośród ważniejszych trosk „miodowego roku” sytuowało się 17,5\% bezrobocia, blisko $3 \%$ spadku produkcji przemysłowej, stagnacja w rolnictwie, sięgająca $8 \%$ inflacja, fatalny bilans handlowy, rosnace zadłużenie zagraniczne ${ }^{59}$ czy chociażby ogłoszenie niepodległości przez Prisztinę 17 lutego 2008 r. W zorganizowanej pięć dni później w Podgoricy przed gmachem parlamentu demonstracji, uczestniczący w niej politycy wyrażali oburzenie swoich rodaków: „Jesteśmy tu razem, by wysłać wiadomość, że nikt w Czarnogórze nie powinien ośmielić się uznawać państwowości Kosowa”, przekonując, że „to obowiązek odrzucić politykę dyktatu, która odbiera kolebkę prawowitemu narodowi” ${ }^{\circ 0}$.

${ }^{58}$ A. Skieterska, Czarnogóra, „Europa Środkowo-Wschodnia. 2008”, ISP PAN, R. XVIII, Warszawa 2010, s. 114.

59 Dane za: Montenegro 2008 Progress Report.

${ }^{60}$ Kosovo Protest by Montenegro, Balkan Investigative, Reporting Network, 23 II 2009, http://balkaninsight.com/en/main/news/8125. 
Mianowany tydzień po manifestacjach ${ }^{61}$, po raz szósty, na urząd premiera, M. Đukanović jeszcze w styczniu, przed „proklamacją samodzielności” zapowiadał, że Czarnogóra, w tej sprawie „będzie zachowywała się zgodnie ze stanowiskiem Unii Europejskiej, jakkolwiek nie będzie się nadmiernie z tym spieszyc'”' ${ }^{\prime 2}$. Może opieszale, zwłaszcza jeśli odnieść to np. do Polski, jednakże Podgorica byt prisztiński uznała (czyniąc to wspólnie z Macedonia) 9 października 2008 r. Na zarzuty opozycji, że rząd uległ presji zagranicznej, decydenci odpowiadali rezolutnie, że w ostatecznym rachunku przeważyła potrzeba wzmocnienia partnerstwa Podgoricy z państwami członkowskimi UE i NATO.

Do demonstracji przeciwko decyzji doszło cztery dni później, a w wyniku starć pod parlamentem rannych zostało 22 uczestników, 12 policjantów, a 35 osób aresztowano. Decydujące areopagi formacji proserbskich czy też grupujacych byłych unionistów, przede wszystkim jednak ugrupowania narodowców żądały, by zorganizować w kwestii uznania Kosowa referendum, a po nim przedterminowe wybory. Temperaturę podnosił Belgrad ogłaszając, że „zdrada” czarnogórska zagraża stabilizacji regionu i może wywołać dalsze napięcia (V. Jeremić nazwał ja , ,ciosem w plecy” zadanym przez tradycyjnego sojusznika ${ }^{63}$.

Obok „bałkańskiego podwórka” Czarnogóra przykładała od początku dużą wagę do integracji europejskiej i atlantyckiej. W październiku 2007 r. podpisała umowę stowarzyszeniowa z UE oraz porozumienie tymczasowe dotyczące handlu i spraw handlowych pomiędzy Wspólnota a krajami kandydackimi, które weszło w życie w styczniu $2008 \mathrm{r}$. W tym samym miesiącu zaczęły obowiązywać umowy o obowiązkach wizowych i readmisji, na mocy których dla studentów, naukowców, biznesmenów czy dziennikarzy wprowadzono ułatwienia w przemieszczaniu się w obszarze Schengen. W kwietniu utworzono Radę Integracji, w skład której weszli przedstawiciele parlamentu, rządu, organizacji pozarządowych, w czerwcu rząd przyją narodowy plan działań do roku 2012, zakładajacy m.in. spełnienie kryteriów niezbędnych do wdrożenia umowy stowarzyszeniowej. Nim minęło lato przejść miała przez kraj pierwsza fala sceptycyzmu, kiedy Unia wyasygnowała (w sierpniu) oczekiwane środki na rozwój państwa w latach 2008-2010. Niespełna $33 \mathrm{mln}$ euro, mających wesprzeć samorządy, rynek pracy, obszary wiejskie i inne dziedziny życia społecznego nie spełniły powszechnych oczekiwań.

Z drugiej strony, w dorocznym raporcie, oceniajacym postępy krajów aspirujących, Komisja Europejska stwierdziła, że chociaż parlament Czarnogóry od października 2007 do listopada 2008 r. przyjął 114 ustaw, to nie wykorzystywał w pełni możliwości wszystkich gremiów, a także nie przykładał należytej

61 To jest 29 lutego $2008 \mathrm{r}$.

62 A. Skieterska, dz. cyt., s. 116.

${ }^{63}$ New Warning for Montenegro over Kosovo, Balkan Insight, 2008 November, http:// www.balkaninsight.com/en/main/news/13759. 
wagi do przestrzegania zasad. W Brukseli zauważono niemniej, że „poczyniono pewne kroki, by poprawić jakość jego pracy" (np. dostępność w Internecie stenogramów posiedzeń plenarnych). Mankamentem pozostawała - co podkreślano dobitnie - słaba działalność Komisji ds. stosunków międzynarodowych i integracji ${ }^{64}$. Bez względu na niedajace się $\mathrm{w}$ przyspieszonych procedurach zniwelować trudności, 15 grudnia 2008 r., pod koniec prezydencji francuskiej, M. Đukanović złożył na ręce Nikolasa Sarkozy'ego w Pałacu Elizejskim oficjalny wniosek o członkostwo w UE.

Czarnogóra, plasująca się wśród organizmów obszarowo skromnych mniejszych niż Słowenia czy Macedonia, choć większa od Cypru czy np. Kataru, stanowi - w postronnej opinii, zważywszy na bilans otwarcia - przykład powodzenia. Z dużą dozą wyrozumiałości postrzegać trzeba fakt, że miejscowi politycy lubią porównywać ją do Monako, snując perspektywy zbudowania nad Zatoką Kotorską kasynowego imperium. Od 2006 r., statystycznie, kraj przyciaga zagraniczne inwestycje warte rocznie ponad $640 \mathrm{mln}$ eur ${ }^{65}$, co powoduje, że w rankingu per capita plasuje się on w... europejskiej czołówce. Nie oznacza to, że światowy kryzys ekonomiczny nie dał o sobie znać i tu: odczuł go dotkliwie rynek kapitałowy, sektor budowlany i bankowy, niwecząc nadzieje na rychłe powtórzenie blisko 7\% wzrostu gospodarczego z lat 2007-2008.

Na progu samodzielności systematycznie przybywało zagranicznych inwestycji; według statystyk ich rekordową wartość wyznaczało ponad $900 \mathrm{mln}$ euro, z czego ok. 53\% przypadło na rynek nieruchomości. Prognozy, że rokrocznie na wybrzeże przybywać będzie coraz to więcej gości, nie było szacowaniem bezpodstawnym. Ekonomistów nie dziwi, że w ostatnich trzech latach nastapił wzrost dochodów gospodarstw domowych, przyczyniając się do zwiększania konsumpcji nawet do $18 \%{ }^{66}$, co stanowi jednak według nich głownie rezultat niskiego „punktu odbicia”.

Czy szacunki unijnych ekspertów, że ponad 85\% przedsiębiorstw należących niegdyśs do państwa zostało sprywatyzowanych, są dobrym prognostykiem? To zależy: w ręce obcych inwestorów oddano w końcu kluczowe sektory, takie jak bankowy czy telekomunikacyjny, nabywców znalazło wiele z turystycznych obiektów. Resursy te nie sa jednak nieograniczone. Zagranicznym podmiotom przeszkadza - używając eufemizmu - niedoskonałe prawo, a utworzona w połowie 2008 r. Rada do spraw eliminacji barier biznesowych pozostała jeszcze jednym ciałem niewydolnym. Pozostaje unikanie podatków, powszechna korupcja, wykazująca według raportów Transparency International ${ }^{67}$, systematyczną progresję.

${ }^{64} \mathrm{Za}$ : Kalendarium wydarzeń w Europie Środkowo-Wschodniej 2008 (opr. A. Skieterska), „Europa Środkowo-Wschodnia. 2008”, ISP PAN, R. XVIII, Warszawa 2010, s. 444.

$65 \mathrm{Za}$ : Montenegro 2008...

${ }_{66}$ Tamże, s. 23.

${ }^{67}$ Zob. Transparency International Corruption Perceptions Index 2009, http://www. transparency.org/policy_research/surveys_indices/cpi/2009/cpi_2009_table. 
Niełatwo jest prognozować przyszłość Czarnogóry, wiele zależy od koniunktury światowej, wcale nie mniej od tego czy przyjęcie Chorwacji do UE zatrzyma, jak zdaja się sygnalizować politycy brukselscy, na długo proces rozszerzania tej agregacji o nowych członków. Bogactwem Czarnogóry są centra turystyczno-wypoczynkowe i nautyczne, potencjał wynikający z urokliwości wybrzeża i wysp, wreszcie - lasy, pokrywające ponad 5 tys. hektarów. Na eksploatację złóż boksytów, rud cynku, ołowiu czy węgla brunatnego trzeba by nakładów, na które w aktualnej sytuacji kraju nie stać. Dotyka go strukturalne bezrobocie - nawet jeśli 23-procentowe nie jest uważane w regionie za alarmujące czy nie przełoży się ono jeszcze silniej na dolegliwości ekonomiczne? Czy wreszcie, jeden z najniższych wskaźników przyrostu naturalnego, na poziomie - 1,6\%, przy $18 \%$ populacji muzułmańskiej, cieszącej się dzietnością pozwalającą odnotować wzrost rzędu $2,8 \% 0^{68}$ jest bombą demograficzną czy też może panaceum na starzenie się społeczeństwa? Symulacje pokazuja że przy obecnych tendencjach prokreacyjnych w roku 2040 proporcje etnozbiorowości z kręgu prawosławia do islamu kształtować się moga jak 59\% do 41\%, co - niewykluczone - będzie zmuszać do ,jednoczenia się” korpusu czarnogórsko-serbskiego. Pytanie brzmi: czy w ogóle warto spekulować na ten temat i czy na Bałkanach diagnoza owa (jak każda inna ich dotycząca) nie jest obarczona niebezpieczeństwem zbyt wielkiego błędu badacza?

68 Zob.: Statistički godišnjak Crne Gore, Podgorica 2010, s. 42; Popis stanouništva, domačinstva i stanova u Crnoj Gori 2011, godine, Podgorica 2011, s. 8-9. 